\title{
Multiple Sklerozlu Kişilerde Serbest Zaman Aktivite Tercihlerinin İncelenmesi
}

\author{
Examination of Leisure Time Activity Preferences of Multiple Sclerosis Patient
}

Büşra YILDIZ1, Burcu Semin AKEL ${ }^{2}$

${ }^{1}$ Ergoterpist, Hacettepe Üniversitesi Sağlık Bilimleri Fakültesi Ergoterapi Bölümü, Ankara

${ }^{2}$ Doç. Dr., Hacettepe Üniversitesi Sağlık Bilimleri Fakültesi Ergoterapi Bölümü, Ankara

\section{öz}

Amaç: Bu çalışma multiple sklerozlu (MS) kişilerin yaptığı serbest zaman aktivite tercihlerini belirlemek ve MS tanısı ile değişen serbest zaman aktivitelerini saptamak amacıyla yapıldı. Gereç ve Yöntem: Çalışma Ocak - Nisan 2017 tarihleri arasında yapıldı. Çalışmaya MS tanısı almış 18-65 yaş arasında 20 kişi dahil edildi. Katılımcıların 15'i kadın 5'i erkek idi. Kişilerin ilk olarak sosyodemografik bilgileri alındı ve ardından 11 sorudan oluşan yarı-yapılandırılmış görüşme yapıldı. Görüşmenin ilk 7 sorusu MS tanısı konduktan sonraki ve son 4 sorusu MS tanısı kanmadan önceki serbest zaman aktivite tercihlerini belirlemeye yönelikti. Sonuçlar: Kişiler MS tanısı aldıktan sonraki serbest zaman aktivitelerinde \%32,49 sessiz rekreasyon aktivitelerini, \%28,51 aktif rekreasyon aktivitelerini ve \%38,98 sosyalizasyon aktivitelerini tercih ettikleri belirlendi. Aktiviteleri çoğunlukla evde ve yalnız yaptıkları belirlendi. MS tanısı aldıktan sonra aktivite tercihlerinin değiştiği saptandı. Kişilerin tanı almadan önce tercih ettikleri aktivitelerde daha fazla zaman harcadıkları belirlendi. Tartışma: MS tanılı bireylerin sosyalizasyon ve sessiz rekreasyon aktivitelerini tercih etmektedirler. Katılımcıların aktivite tercihleri gelişen limitasyonlara bağlı olarak değişmektedir.

Anahtar Kelimeler: Multiple Skleroz; Serbest zaman aktiviteleri; Ergoterapi

\section{ABSTRACT}

Purpose: This study was to determine the leisure time activities preferences of multiple sclerosis (MS) patients and the changes in leisure time activities associated with MS. Material and Methods: The study was conducted between January and April 2017. 15 female and 5 male between 18-65 years old who were diagnosed with MS were included in this study. First, socio-demographic information of the people was taken and then a semi-structured interview consisted 11 questions was made with them. The first 7 questions of the interview were for determining the leisure time activity preferences after the diagnosis of MS and the last 4 questions were before the diagnosis of MS. Results: After the people got MS diagnosis, they prefer $32.61 \%$ of quiet recreation, $29.03 \%$ of active recreation and $38.35 \%$ of socialization in their leisure time activities, and they mostly made the activities at home and alone. After getting MS diagnosis, their activity preferences changed and their activity time became less than before. Conclusion: It was seen that individuals with MS preferred socialization and quiet recreation. Participants' activity preferences changed after the diagnosis limitations.

Key Words: Multiple Sclerosis; leisure activities; Occupational therapy 
AOTA tarafından tanımlanan aktiviteler günlük yaşam aktiviteleri, iş ve üretici aktiviteler ve serbest zaman aktiviteleri olmak üzere üç performans alanını kapsar. Üç aktivite alanı arasında dengeyi sağlamak iyilik halini korumada önemlidir (Edgelow ve Krupa, 2011). Serbest zaman aktivitelerinde yeterli katılım olmazsa aktivite dengesi kişinin sağlığını etkileyecek şekilde bozulacaktır (American Journal of Occupational Therapy, 2014).

Serbest zaman aktiviteleri, "serbest zaman (iş, kişisel bakım ya da uyku gibi zorunlu aktivitelerin dışındaki zamanda) boyunca motivasyon ile gerçekleştirilen zorunlu olmayan eylemlerdir " (American Journal of Occupational Therapy, 2014). Serbest zaman aktiviteleri okuma ve el sanatları gibi aktiviteleri içeren sessiz rekreasyon, seyahat ve spor gibi aktiviteleri içeren aktif rekreasyon ve aile ve arkadaş ziyaretleri gibi aktiviteleri içeren sosyalizasyon bölümlerinden oluşmaktadır (Hersch, Lamport ve Coffey, 2005). Serbest zaman aktiviteleri, kişilerin kültürel ve toplumsal yapısına bağlı olabilir. Kültürlerdeki farklılıklar, serbest zaman aktivitelerinde türü, hedefi ve katılım seviyesini etkiyebilir (McHugh Pendleton ve Schultz-Krohn, 2013).

Serbest zaman aktivitelerine katılım, kişinin öz farkındalığı ile ilişkilidir ve sağlıklı yaşam biçiminin bir parçasıdır (Chang, Fang, Ling ve ark, 2011). Fakat serbest zaman aktiviteleri, bozukluklar tarafından kısıtlanabilir. Serbest zaman aktivitelerini kısıtlayan sağlık durumlarından biri multiple skleroz olarak adlandırılan nörolojik bir hastalıktır (Etemadifar, Izadi, Nikseresht ve ark, 2014).

Multiple skleroz (MS), fiziksel bozukluğa neden olan, genç nüfusu etkileyen, ataklar ve remisyonlarla seyreden kronik bir hastalıktır (Murray, 2005). Dünyada MS tanısı almış kişi sayısı her yıl artmaktadır. MS'li kişilerde serbest zaman aktivitelerini de içeren tüm günlük yaşam aktiviteleri kısıtlayan depresyon, yorgunluk ve kognitif bozukluklar gibi çeşitli komplikasyonlar ortaya çıkabilir (Shevil, Johansson, Ytterberg ve ark, 2014) ve bu nedenle; kişilerin iyilik hali ve yaşam kaliteleri olumsuz etkilenir (Marrie, Horwitz, Cutter ve ark, 2012). MS'li kişilerde hastalığın bulgularına ve bulguların neden olduğu engel durumunu azaltmak amacıyla terapatik yaklaşımlara daha fazla odaklanılmasından dolayı serbest zaman aktiviteleri göz ardı edilmektedir (Vanner, Block, Christodoulou ve ark, 2008). Serbest zaman aktivitelerine katılımın arttırılması kişilerin bulgularının ve bulguların neden olduğu engel durumunun azalmasına yardım edebilir ve böylelikle kişilerin ailelerindeki ve sosyal çevrelerindeki kişilerde hastalığın yükü azaltılabilir (Radomski ve Latham, 2008).

Türkiye'de MS hastalarındaki serbest zaman aktivite tercihleri bilinmemektedir. Kültüre bağlı serbest zaman aktivitelerinin değişiklik gösterdiği düşünülerek bu çalışma planlandı. Bu çalışma MS'li kişilerin yaptığı serbest zaman aktivite tercihlerini belirlemeyi ve MS tanısı ile değişen serbest zaman aktivitelerini saptamayı amaçlamaktadır.

Çalışmanın temel soruları şu şekildedir; MS'li kişilerin yaptığı serbest zaman aktiviteler nelerdir? Hastalık ile aktivite tercihleri değişmekte midir?

\section{GEREÇ VE YÖNTEM}

Çalışmaya MS tanısına sahip erişkin bireylerin alınması planlandı. Bu kişiler için dahil edilme kriterleri; bireylere MS tanısının nörolog tarafından konulmuş olması, bireylerin 18 yaş ve üzeri olması ve bireylerin çalışmaya katılmayı kabul etmesidir. Çalışmaya dahil edilen MS tipleri; Ataklarla seyreden (RMMS-akut atakları izleyen tam ya da tama yakın düzelme dönemleri mevcuttur), sekonder progresif (SPMS-ortalama 5-6 yıllık erken dönem sonrası ikincil ilerleyici dönemdir) ve progresif-relapsing (başlangıçtan itibaren ataklar yaşansa da sürekli bir ilerleme mevcuttur). Çalışmaya dahil edilmeme kriterleri; Primer progresif multiple skleroz (PPMS-genellikle iyileşme kaydedilmeden, başlangıçtan itibaren hastalığın ilerlemesi ile karakterize seyir gösteren tablodur) tanısına sahip olmak ve birebir görüşmede sözlü olarak iletişim kuramamak (Ünal, Mavioğlu ve Emre, 2013). Çalışma Ocak - Nisan 2017 aralığında gerçekleştirildi. Çalışmaya 20 kişi dahil edildi. Değerlendirmeden önce kişilere çalışmanın içeriği hakkında bilgi verildi ve kişilere onam formu imzalatıldı. Çalışma Helsinki Deklarasyonu Prensipleri'ne uygun olarak yapıldı.

Değerlendirme için yarı-yapılandırılmış görüşme soruları hazırlandı. Bu sorular serbest zaman aktivite tercihlerini belirlemeye yöneliktir. Görüşmelerde ilk olarak sosyo-demografik özellikler soruldu ve ardından yarı-yapılandırılmış görüşme yapıldı. 18 kişi ile görüşme MS derneğinde, 2 kişi ile Hacettepe Üniversitesi Ergoterapi bölümünde yapıldı. Görüşmeler esnasında ses kaydı alındı.

Görüşmeye başlamadan önce kişilere serbest zaman aktiviteleri hakkında bilgi verildi. Yapılan görüşme 11 sorudan oluşmaktadır. Sorular MS'li kişilerin serbest zaman aktivitelerini belirleyen nitel bir çalışmadan kaynak alınarak çeşitlendirildi (Hosseini, Asgari, Rassafiani ve ark, 2016). 7 soru MS tanısı aldıktan sonraki ve 4 soru MS tanısı 
almadan önceki serbest zaman aktivitelerini belirlemeye yöneliktir. İlk 7 soru;

- Serbest zamanınızı nasıl geçiriyorsunuz?

- Serbest zaman aktivitelerinizi ne sıklıkla yapıyorsunuz ve ne kadar sürüyor?

- Farklı hangi serbest zaman aktivitelerini mevsimlerde göre değişiyor mu?

- Hafta içi ve hafta sonları hangi serbest zaman aktivitelerini yaparsınız?

- Serbest zaman aktivitelerinizi beraber yaptığınız kişiler var mı?

- Serbest zaman aktivitelerinizi nerede gerçekleştiriyorsunuz?

- Serbest zaman aktivitelerinizi nasıl gerçekleştiriyorsunuz?

Ve son 4 soru;

- MS tanısı almadan önce serbest zamanlarınızı nasıl geçiriyordunuz? Neler yapardınız? Serbest zaman aktivitesini ne sıklıkla yapıyorsunuz ve ne kadar sürüyor?

- MS tanısı almadan önce serbest zaman aktivitelerinizi kimlerle yapardınız?

- MS tanısı almadan önce serbest zaman aktivitelerinizi nerede yapardınız?

- Serbest zaman aktivitelerinizi hastalığınız etkiliyor mu? MS tanısı konduktan sonra serbest zaman aktivitelerinizde değişim oldu mu?

Çalışmanın analizi belirlenen aktivitelerin çeşitleri, sıklıkları, ne zaman, nerede, kimlerle ve nasıl yapıldığı MS öncesi ve sonrası şeklinde IBM SPSS Statistics 20 Programı kullanılarak sınıflandırıldı. Ayrıca aktivite tercihleri sosyodemografik bilgilere göre de IBM SPSS Statistics 20 Programı kullanılarak yüzde cinsinden sınıflandırıldı.

Çalışma verilerinin analizi nitel araştırma tekniklerden içerik analizi kullanılarak çözümlendi. Katılımcıların her bir soruya verdiği cevaplar benzerliklerine göre gruplandırılarak yorumlandı ve yüzde cinsinde sınıflandırıldı, ayrıca her soruya verilen birkaç cevap da aynen sunulma yoluna gidildi (Yıldırım ve Şimşek, 2016).

\section{SONUÇ}

Demografik Bilgiler

Katılımcılar 30-63 yaş aralığındadır ve yaş ortalaması 47,10 $\pm 9,37$ 'dir. Katılımcıların 15'i kadın (\%75) ve 5'i erkektir (\%25). Kişilerin 12'si evli (\%60), 2 'si bekar (\%10) ve 6'sı duldur (\%30). Katılımcıların 15 'inin annesi (\%75) ve 12'sinin babası (\%60) sağdır ve 19'unun kardeşi (\%95) vardır. Kardeş sayısı 1 ile 6 arasında değişmektedir ve ortalama 2,94ะ1,43'tür. 14 kişinin çocuğu (\%70) vardır. Çocuk sayısı 1 ile 2

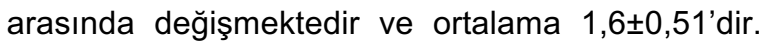
Kişilerin çoğunun üniversite mezunu (\%35), emekli (\%35) ve eşi ile beraber (\%30) yaşadığı bulundu. Katılımcıların eğitim düzeyi, çalışma durumu ve kaldığı yerde beraber yaşadığı kişiler Tablo 1'de verilmiştir. Katılımcıların MS tanısına sahip olma süreleri 3 ile $30 \mathrm{yıl}$ arasında değişmektedir ve

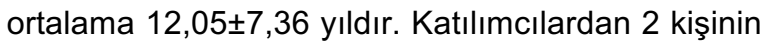
(\%10) evcil hayvanı (kedi ve balık) vardır. 4 katılımcı sigara (\%20) ve 2 katılımcı alkol (\%10) kullanmaktadır.

Tablo 1. Eğitim düzeyi, çalışma durumu ve yaşadığı kişiler ile ilgili bulgular

\begin{tabular}{lcc}
\hline Eğitim Düzeyi & Sayı & Yüzde (\%) \\
\hline İlkokul mezunu & 2 & 10 \\
\hline Ortaokul mezunu & 5 & 25 \\
\hline Lise mezunu & 6 & 30 \\
\hline Üniversite mezunu & 7 & 35 \\
\hline Çalışma Durumu & Sayı & Yüzde (\%) \\
\hline Hiç çalışmamış & 3 & 15 \\
\hline Önceden çalışmış ama şimdi çalışmıyor & 4 & 20 \\
\hline Çalışıyor & 6 & 30 \\
\hline Emekli & 7 & 35 \\
\hline Yaşadığı Kişiler & Sayı & 5 \\
\hline Yalnız & 1 & 25 \\
\hline Aile (anne, baba ve kardeş) & 5 & 30 \\
\hline Eşi & 6 & 25 \\
\hline Eşi ve çocukları & 5 & 10 \\
\hline Çocuklarıla & 2 & 5 \\
\hline Kardeşlerle & 1 & üzde (\%) \\
\hline
\end{tabular}


Serbest Zaman Aktivitelerine Ait Bulgular

Katılımcılar hastalık sonrası serbest zaman aktivitelerinde sessiz rekreasyon $(\% 32,49)$ ve sosyalizasyon $(\% 38,98)$ aktivitelerini tercih etmektedir. Sessiz rekreasyon aktivitelerinde ilk sıralarda televizyon seyretme, müzik dinleme ve kitap okuma aktivitelerini yaptıkları belirlendi.
Sosyalizasyon aktivitelerinde ise ilk sıralarda misafirliğe gitme, telefonla konuşma ve Multiple Skleroz Derneği'nde vakit geçirme aktivitelerini yaptıkları saptandı. Sessiz rekreasyon, aktif rekreasyon ve sosyalizasyon aktivitelerinin yüzdeleri, sıklıkları ve süreleri Tablo 2, Tablo 3 ve Tablo 4'te verilmiştir.

Tablo 2. MS sonrası sessiz rekreasyon aktivitelerinin sıklıkları, süreleri ve yüzdeleri

\begin{tabular}{|c|c|c|c|c|c|c|c|}
\hline \multirow{3}{*}{ Aktivite } & \multirow{3}{*}{ Sayı } & \multicolumn{2}{|c|}{ Sessiz Rekreasyon } & $\% 32,49$ & \multirow{2}{*}{\multicolumn{3}{|c|}{ Süre }} \\
\hline & & \multirow{2}{*}{$\begin{array}{c}\text { Yüzde } \\
(\%)\end{array}$} & \multicolumn{2}{|c|}{ Sıklık } & & & \\
\hline & & & Sıklık & Yüzde (\%) & Min & Max & Ortalama \\
\hline \multirow[t]{3}{*}{ Televizyon Seyretme } & 17 & 85 & Her Gün & 88,23 & 0,25 Saat & 9 Saat & 3,13 Saat \\
\hline & & & Haftada $1 \mathrm{Kez}$ & 5,88 & & & \\
\hline & & & Haftada $2 \mathrm{Kez}$ & 5,88 & & & \\
\hline \multirow[t]{3}{*}{ Müzik Dinleme } & 12 & 60 & Her Gün & 75 & 5 Dakika & 120 & 45,41 Dakika \\
\hline & & & Haftada $3 \mathrm{Kez}$ & 16,66 & & Dakika & \\
\hline & & & 2 Haftada $1 \mathrm{Kez}$ & 8,33 & & & \\
\hline \multirow{5}{*}{ Kitap Okuma } & 11 & 55 & Her Gün & 45,45 & 0,25 Saat & 2 Saat & 0,68 Saat \\
\hline & & & Haftada $1 \mathrm{Kez}$ & 27,27 & & & \\
\hline & & & Haftada $3 \mathrm{Kez}$ & 9,09 & & & \\
\hline & & & 2 Haftada $1 \mathrm{Kez}$ & 9,09 & & & \\
\hline & & & Ayda $1 \mathrm{Kez}$ & 9,09 & & & \\
\hline Namaz kılma & 8 & 40 & Her Gün & 100 & & & \\
\hline \multirow[t]{3}{*}{ Çiçek bakımı (sulama) } & 5 & 25 & Her Gün & 60 & 5 Dakika & 20 Dakika & 10 Dakika \\
\hline & & & 2 Günde $1 \mathrm{kez}$ & 20 & & & \\
\hline & & & Ayda $1 \mathrm{Kez}$ & 20 & & & \\
\hline \multirow{3}{*}{ Kur'an Okuma } & 5 & 25 & Her Gün & 60 & 30 Dakika & 90 Dakika & 60 Dakika \\
\hline & & & 2 Günde $1 \mathrm{Kez}$ & 20 & & & \\
\hline & & & Haftada $1 \mathrm{Kez}$ & 20 & & & \\
\hline $\begin{array}{l}\text { Sosyal medya ve internet } \\
\text { kullanma }\end{array}$ & 4 & 20 & Her Gün & 100 & 0,25 Saat & 4 Saat & 1,56 Saat \\
\hline $\begin{array}{l}\text { Bilgisayardan haber } \\
\text { izleme }\end{array}$ & 3 & 15 & Her Gün & 100 & 1 Saat & 4 Saat & 2,33 Saat \\
\hline \multirow[t]{2}{*}{ Gazete okuma } & 3 & 15 & Her Gün & 66,66 & 0,25 Saat & 1 Saat & 0,58 Saat \\
\hline & & & Haftada $1 \mathrm{Kez}$ & 33,33 & & & \\
\hline \multirow{3}{*}{$\begin{array}{l}\text { Yemek yapma (pasta, } \\
\text { börek, tarif deneme vb.) }\end{array}$} & 3 & 15 & 2 Günde $1 \mathrm{Kez}$ & 33,33 & 30 Dakika & 60 Dakika & 43,3 Dakika \\
\hline & & & Haftada $1 \mathrm{Kez}$ & 33,33 & & & \\
\hline & & & 10 Günde $1 \mathrm{Kez}$ & 33,33 & & & \\
\hline \multirow[t]{2}{*}{ Bulmaca çözme } & 2 & 10 & 3 Günde $1 \mathrm{Kez}$ & 50 & 5 Dakika & 20 Dakika & 12,5 Dakika \\
\hline & & & Haftada $1 \mathrm{Kez}$ & 50 & & & \\
\hline \multirow{2}{*}{$\begin{array}{l}\text { Deniz kenarında vakit } \\
\text { geçirme }\end{array}$} & 2 & 10 & Yılda 7 Gün & 50 & 1 Saat & 2 Saat & 1,5 Saat \\
\hline & & & Yılda 12 Gün & 50 & & & \\
\hline Film izleme & 2 & 10 & & & 2 Saat & 2 Saat & 2 Saat \\
\hline \multirow[t]{2}{*}{ Okey oynama } & 2 & 10 & Her Gün & 50 & 1 Saat & 5 Saat & 3 Saat \\
\hline & & & Ayda $1 \mathrm{Kez}$ & 50 & & & \\
\hline Örgü örme & 2 & 10 & Her Gün & 100 & 1 Saat & 3,5 Saat & 2,25 Saat \\
\hline Tığ-dantel yapma & 2 & 10 & Her Gün & 100 & 1 Saat & 2 Saat & 1,5 Saat \\
\hline $\begin{array}{l}\text { Akıl oyunları (sudoku, } \\
\text { kakuro vb.) }\end{array}$ & 1 & 5 & Ayda $1 \mathrm{Kez}$ & 100 & 0,5 Saat & 0,5 Saat & 0,5 Saat \\
\hline Belgesel izleme & 1 & 5 & Her Gün & 100 & 2 Saat & 2 Saat & 2 Saat \\
\hline Dergi okuma & 1 & 5 & 3 Günde $1 \mathrm{Kez}$ & 100 & 20 Dakika & 20 Dakika & 20 Dakika \\
\hline $\begin{array}{l}\text { Kart oyunları oynama (pişti } \\
\text { vb.) }\end{array}$ & 1 & 5 & 3 Günde $1 \mathrm{Kez}$ & 100 & 2 Saat & 2 Saat & 2 Saat \\
\hline Takı yapımı & 1 & 5 & Her Gün & 100 & 1 Saat & 1 Saat & 1 Saat \\
\hline Tavla oynama & 1 & 5 & Haftada $1 \mathrm{Kez}$ & 100 & 3 Saat & 3 Saat & 3 Saat \\
\hline Tespih çekme & 1 & 5 & Her Gün & 100 & 30 Dakika & 30 Dakika & 30 Dakika \\
\hline
\end{tabular}


Tablo 3. MS sonrası aktif rekreasyon aktivitelerinin sıklıkları, süreleri ve yüzdeleri

\begin{tabular}{|c|c|c|c|c|c|c|c|}
\hline \multirow{3}{*}{ Aktivite } & \multirow{3}{*}{ Sayı } & \multicolumn{2}{|c|}{ Aktif Rekreasyon } & \multirow[t]{2}{*}{$\% 28,51$} & \multirow{2}{*}{\multicolumn{3}{|c|}{ Süre }} \\
\hline & & \multirow{2}{*}{$\begin{array}{c}\text { Yüzde } \\
(\%)\end{array}$} & Sıklık & & & & \\
\hline & & & Sıklık & Yüzde (\%) & Min & Max & Ortalama \\
\hline \multirow[t]{2}{*}{ Yoga yapma } & \multirow[t]{2}{*}{12} & \multirow[t]{2}{*}{60} & Haftada $1 \mathrm{Kez}$ & 83,33 & \multirow[t]{2}{*}{3 saat } & \multirow[t]{2}{*}{3 saat } & \multirow[t]{2}{*}{3 saat } \\
\hline & & & Haftada $2 \mathrm{Kez}$ & 16,66 & & & \\
\hline \multirow[t]{2}{*}{ Yürüyüş } & \multirow[t]{2}{*}{11} & \multirow[t]{2}{*}{55} & Her Gün & 81,81 & \multirow[t]{2}{*}{15 dakika } & \multirow{2}{*}{120 dakika } & \multirow[t]{2}{*}{48,18 dakika } \\
\hline & & & 2 Günde 1 & 18,18 & & & \\
\hline \multirow[t]{2}{*}{ Tatile çıkma } & \multirow[t]{2}{*}{9} & \multirow[t]{2}{*}{45} & Yılda $1 \mathrm{Kez}$ & 77,77 & \multirow[t]{2}{*}{7 gün } & \multirow[t]{2}{*}{90 gün } & 20,22 gün \\
\hline & & & Yılda $2 \mathrm{Kez}$ & 22,22 & & & \\
\hline & 6 & 30 & 3 Haftada $1 \mathrm{Kez}$ & 25 & 2 saat & 2 saat & 2 saat \\
\hline Sinemaya gitme & & & Ayda $1 \mathrm{Kez}$ & 25 & & & \\
\hline & & & 2 Ayda $1 \mathrm{Kez}$ & 25 & & & \\
\hline & & & Yılda $5 \mathrm{Kez}$ & 25 & & & \\
\hline & 6 & 30 & Yılda 7 Gün & 33,33 & 1 saat & 3 saat & 1,5 saat \\
\hline Yüzme & & & Yılda 20 Gün & 16,66 & & & \\
\hline & & & Yılda 30 Gün & 16,66 & & & \\
\hline & & & Yılda 60 Gün & 33,33 & & & \\
\hline Koro & 5 & 25 & 2 Haftada $1 \mathrm{Kez}$ & 100 & 2 saat & 2 saat & 2 saat \\
\hline Çocuklarla oyun oynama & 4 & 20 & Her Gün & 50 & 1 saat & 8 saat & 3,75 saat \\
\hline (boğuşma, oyuncaklarla & & & Haftada $2 \mathrm{Kez}$ & 25 & & & \\
\hline oynama vb.) & & & Haftada $5 \mathrm{Kez}$ & 25 & & & \\
\hline & 4 & 20 & Yılda $1 \mathrm{Kez}$ & 33,33 & 0,5 saat & 1 saat & 0,87 saat \\
\hline Meyve ve sebze toplama & & & Yılda $6 \mathrm{Kez}$ & 33,33 & & & \\
\hline & & & Yılda $15 \mathrm{Kez}$ & 33,33 & & & \\
\hline & 3 & 15 & Haftada $2 \mathrm{Kez}$ & 33,33 & 3 saat & 4 saat & 3,5 saat \\
\hline Kursa gitme & & & Haftada $3 \mathrm{Kez}$ & 33,33 & & & \\
\hline & & & Haftada $4 \mathrm{Kez}$ & 33,33 & & & \\
\hline Memlekete gitme & 3 & 15 & Yılda $1 \mathrm{Kez}$ & 100 & 7 gün & 30 gün & 17,33 gün \\
\hline & 3 & 15 & Haftada $1 \mathrm{Kez}$ & 33,33 & 2 saat & 2 saat & 2 saat \\
\hline Tiyatroya gitme & & & 2 Ayda $1 \mathrm{Kez}$ & 33,33 & & & \\
\hline & & & Yılda $5 \mathrm{Kez}$ & 33,33 & & & \\
\hline & 3 & 15 & Her Gün & 33,33 & 20 dakika & 30 dakika & 26,66 dakika \\
\hline Spor yapma & & & Haftada 2 Kez & 33,33 & & & \\
\hline & & & Haftada $3 \mathrm{Kez}$ & 33,33 & & & \\
\hline Camiye gitme & 2 & 10 & Haftada $3 \mathrm{Kez}$ & 100 & 20 dakika & 20 dakika & 20 dakika \\
\hline Evcil hayvan besleme & 2 & 10 & Her Gün & 100 & 0,5 saat & 0,5 saat & 0,5 saat \\
\hline Toprak işleriyle uğraşma & 2 & 10 & Yılda 15 Gün & 50 & 0,5 saat & 1,5 saat & 1 saat \\
\hline (çiçek, sebze ekme vb.) & & & Yılda 90 Gün & 50 & & & \\
\hline $\begin{array}{l}\text { Maç izlemeye gitme } \\
\text { (futbol) }\end{array}$ & 1 & 5 & Haftada $1 \mathrm{Kez}$ & 100 & 2 saat & 2 saat & 2 saat \\
\hline Operaya gitme & 1 & 5 & Ayda $1 \mathrm{Kez}$ & 100 & 2 saat & 2 saat & 2 saat \\
\hline Pilates yapma & 1 & 5 & Haftada $3 \mathrm{Kez}$ & 100 & 1 saat & 1 saat & 1 saat \\
\hline $\begin{array}{l}\text { Türk sanat müziği } \\
\text { dinlemeye gitme }\end{array}$ & 1 & 5 & Ayda $2 \mathrm{Kez}$ & 100 & 2 saat & 2 saat & 2 saat \\
\hline
\end{tabular}


Tablo 4. MS sonrası sosyalizasyon aktivitelerinin sıklıkları, süreleri ve yüzdeleri

\begin{tabular}{|c|c|c|c|c|c|c|c|}
\hline \multirow{3}{*}{ Aktivite } & \multirow{3}{*}{ Sayı } & \multirow{3}{*}{$\begin{array}{l}\text { Yüzde } \\
(\%)\end{array}$} & \multirow{2}{*}{\multicolumn{2}{|c|}{$\begin{array}{r}\text { Sosyalizasyon } \\
\text { Sıklık }\end{array}$}} & & & \\
\hline & & & & & \multicolumn{3}{|c|}{ Süre } \\
\hline & & & Sıklık & Yüzde (\%) & Min & Max & Ortalama \\
\hline \multirow{5}{*}{ Misafirliğe Gitme } & 17 & 85 & Her Gün & 12,5 & 0,5 Saat & 8 Saat & 2,89 Saat \\
\hline & & & 3 Günde $1 \mathrm{Kez}$ & 8,33 & & & \\
\hline & & & Haftada $1 \mathrm{Kez}$ & 33,33 & & & \\
\hline & & & Ayda $1 \mathrm{Kez}$ & 41,66 & & & \\
\hline & & & 3 Ayda $1 \mathrm{Kez}$ & 4,16 & & & \\
\hline \multirow{4}{*}{ Telefonla Konuşma } & 15 & 75 & Her Gün & 60 & 2 Dakika & 60 Dakika & 22,26 Dakika \\
\hline & & & 3 Günde $1 \mathrm{Kez}$ & 20 & & & \\
\hline & & & Haftada $1 \mathrm{Kez}$ & 13,33 & & & \\
\hline & & & Haftada 2 Kez & 6,66 & & & \\
\hline \multirow{2}{*}{$\begin{array}{l}\text { Multiple Skleroz } \\
\text { Derneği'nde Vakit } \\
\text { Geçirme }\end{array}$} & 13 & 65 & Haftada $1 \mathrm{Kez}$ & 92,30 & 1 Saat & 6 Saat & 3,08 Saat \\
\hline & & & Haftada $3 \mathrm{Kez}$ & 7,69 & & & \\
\hline \multirow{4}{*}{$\begin{array}{l}\text { Aile İle Birlikte Vakit } \\
\text { Geçirme (Sohbet Vb.) }\end{array}$} & 10 & 50 & Her Gün & 60 & 0,5 Saat & 8 Saat & 2,5 Saat \\
\hline & & & Haftada $2 \mathrm{Kez}$ & 20 & & & \\
\hline & & & Yılda $2 \mathrm{Kez}$ & 10 & & & \\
\hline & & & Yılda 5 Kez & 10 & & & \\
\hline \multirow{7}{*}{$\begin{array}{l}\text { Dış Mekanda Oturma } \\
\text { (Kafe, Park Vb.) }\end{array}$} & 13 & 65 & Her Gün & 6,25 & 0,50 Saat & 6 Saat & 2,43 Saat \\
\hline & & & 2 Günde $1 \mathrm{Kez}$ & 12,5 & & & \\
\hline & & & Haftada $1 \mathrm{Kez}$ & 37,5 & & & \\
\hline & & & 2 Haftada $1 \mathrm{Kez}$ & 12,5 & & & \\
\hline & & & Haftada 2 Kez & 6,25 & & & \\
\hline & & & Ayda $1 \mathrm{Kez}$ & 18,75 & & & \\
\hline & & & Ayda $2 \mathrm{Kez}$ & 6,25 & & & \\
\hline \multirow{6}{*}{ Misafir Kabul Etme } & 13 & 65 & Haftada $1 \mathrm{Kez}$ & 30,76 & 1 Saat & 6 Saat & 3,35 Saat \\
\hline & & & Haftada $2 \mathrm{Kez}$ & 7,69 & & & \\
\hline & & & 2 Haftada $1 \mathrm{Kez}$ & 15,38 & & & \\
\hline & & & 20 Günde $1 \mathrm{Kez}$ & 7,69 & & & \\
\hline & & & Ayda $1 \mathrm{Kez}$ & 38,46 & & & \\
\hline & & & 2 Ayda $1 \mathrm{Kez}$ & 7,69 & & & \\
\hline \multirow{5}{*}{ Avm'de Dolaşma } & 9 & 45 & Haftada $1 \mathrm{Kez}$ & 44,44 & 1 Saat & 6 Saat & 3 Saat \\
\hline & & & Haftada 2 Kez & 11,11 & & & \\
\hline & & & 2 Haftada $1 \mathrm{Kez}$ & 11,11 & & & \\
\hline & & & 3 Haftada $1 \mathrm{Kez}$ & 11,11 & & & \\
\hline & & & Ayda $1 \mathrm{Kez}$ & 22,22 & & & \\
\hline \multirow{4}{*}{ Piknik } & 5 & 25 & Yılda 2 Kez & 40 & 3 Saat & 12 Saat & 6,8 Saat \\
\hline & & & Yılda $3 \mathrm{Kez}$ & 20 & & & \\
\hline & & & Yılda $5 \mathrm{Kez}$ & 20 & & & \\
\hline & & & Yılda $12 \mathrm{Kez}$ & 20 & & & \\
\hline \multirow{3}{*}{$\begin{array}{l}\text { Yatılı Olarak Birinde } \\
\text { Kalma }\end{array}$} & 5 & 25 & 2 Haftada $1 \mathrm{Kez}$ & 60 & 1 Gün & 2 Gün & 1,2 Gün \\
\hline & & & Ayda $1 \mathrm{Kez}$ & 20 & & & \\
\hline & & & Yılda $4 \mathrm{Kez}$ & 20 & & & \\
\hline \multirow{2}{*}{$\begin{array}{l}\text { Multiple Skleroz Derneği } \\
\text { Dışında Bir Deneğe Üye } \\
\text { Olma }\end{array}$} & 3 & 15 & Haftada $1 \mathrm{Kez}$ & 66,66 & 3 Saat & 6 Saat & 4 Saat \\
\hline & & & Ayda $2 \mathrm{Kez}$ & 33,33 & & & \\
\hline Güne Gitme & 2 & 10 & Ayda $1 \mathrm{Kez}$ & 100 & 2 Saat & 3 Saat & 2,5 Saat \\
\hline \multirow[t]{2}{*}{ Yatılı Misafir Kabul Etme } & 2 & 10 & Ayda $1 \mathrm{Kez}$ & 50 & 2 Gün & 10 Gün & 6 Gün \\
\hline & & & Yılda $1 \mathrm{Kez}$ & 50 & & & \\
\hline Gönüllü Annelik & 1 & 15 & Haftada $1 \mathrm{Kez}$ & 100 & 3 Saat & 3 Saat & 3 Saat \\
\hline
\end{tabular}

Kişiler aktivitelerini çoğunlukla yalnız $(\% 31,8)$ ve evde $(\% 35,8)$ yaptıkları belirlendi. Kişilerin MS hastası kişilerle $(\% 13,1)$ diğer arkadaşlarına $(\% 12,4)$ göre daha çok vakit geçirdikleri bulundu. Kişiler dış ortamda yapılan aktivitelerde çoğunlukla kaferestoran $(\% 58,6)$ ve alışveriş merkezini (AVM) $(\% 31,0)$ tercih ettikleri saptandı. Aktivitenin yapıldığı yer ve aktivitelerin birlikte yapıldığı kişiler Tablo 5'te verilmiştir.

Katılımcılar hastalık öncesindeki serbest zaman aktivitelerinde aktif rekreasyon aktivitelerini (\%43,51) tercih etmektedir. Aktif rekreasyon aktivitelerinde ilk sıralarda yürüyüş yapma, tatile çıkma ve sinemaya gitme aktivitelerini yaptıkları belirlendi. Sessiz rekreasyon, aktif rekreasyon ve sosyalizasyon aktivitelerinin yüzdeleri, sıklıkları ve süreleri Tablo 6 ve Tablo 7'de verilmiştir.

Kişiler aktivitelerini çoğunlukla yalnız $(\% 31,4)$ ve arkadaşlarla $(\% 28,8)$; evde $(\% 28,0)$ ve açık havada

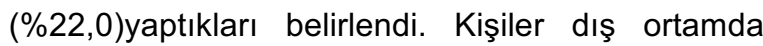
yapılan aktivitelerde kafe-restoran $(\% 63,6)$ yerlere daha çok tercih ettikleri saptandı. Aktivitenin yapıldığı yer ve aktivitelerin birlikte yapıldığı kişiler Tablo 8'de verilmiştir. 
Tablo 5. MS sonrası aktivitenin yapıldığı yerler ve aktivitelerin birlikte yapıldığı kişiler ile ilgili bulgular

\begin{tabular}{|c|c|c|c|c|}
\hline \multirow{9}{*}{ 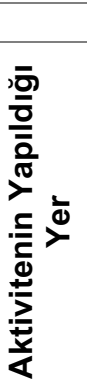 } & & & & Yüzde (\%) \\
\hline & \multicolumn{3}{|l|}{ Yaşadığı ev } & 35,8 \\
\hline & \multicolumn{3}{|c|}{ Topluma açık yerler (dernek, kurs, sinema, tiyatro vb.) } & 19,3 \\
\hline & \multicolumn{3}{|l|}{ Başka birinin evi } & 14,2 \\
\hline & \multicolumn{3}{|l|}{ Açık hava (park, yol vb.) } & 13,1 \\
\hline & \multirow{4}{*}{$\begin{array}{l}\text { Dış ortam (kafe-restoran, kahvehane, } \\
\text { binanın önündeki yer, avm) }\end{array}$} & Kafe-restoran & 58,6 & \multirow[t]{4}{*}{10,9} \\
\hline & & Alış veriş merkezi & 31,0 & \\
\hline & & Kahvehane & 3,4 & \\
\hline & & Binanın önündeki yer-çardak & 6,9 & \\
\hline \multirow{12}{*}{ 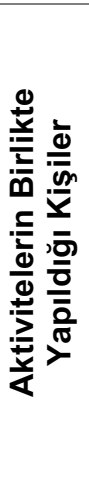 } & \multicolumn{3}{|l|}{ Otel-yazlık } & 3,6 \\
\hline & \multicolumn{3}{|l|}{ Yolda (toplu taşımada, arabada vb.) } & 2,9 \\
\hline & \multicolumn{3}{|l|}{ Yalnız } & 31,8 \\
\hline & \multicolumn{3}{|l|}{ Arkadaşlar (MS hastası kişiler) } & 13,1 \\
\hline & \multicolumn{3}{|l|}{ Anne, baba ya ve kardeş } & 12,4 \\
\hline & \multicolumn{3}{|l|}{ Çocuklarıyla } & 8,4 \\
\hline & \multicolumn{3}{|l|}{ Eş } & 8,4 \\
\hline & \multicolumn{3}{|l|}{ Arkadaşlar } & 8,0 \\
\hline & \multicolumn{3}{|l|}{ Akraba } & 6,6 \\
\hline & \multicolumn{3}{|l|}{ Eşi ve çocuklarıyla } & 5,5 \\
\hline & \multicolumn{3}{|l|}{ Toplum } & 3,3 \\
\hline & \multicolumn{3}{|l|}{ Komşu } & 2,6 \\
\hline
\end{tabular}

Tablo 6. MS öncesi sessiz rekreasyon ve sosyalizasyon aktivitelerinin sıklıkları, süreleri ve yüzdeleri

\begin{tabular}{|c|c|c|c|c|c|c|c|c|}
\hline & Aktivite & Sayı & Yüzde (\%) & Sıklık & & & Süre & \\
\hline & Kitap okuma & 6 & 30 & Her Gün & 50 & 0,25 & 4 Saat & 1,45 Saat \\
\hline & & & & Haftada $1 \mathrm{Kez}$ & 50 & Saat & & \\
\hline 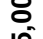 & Örgü örme & 6 & 30 & Her Gün & 66,66 & 1 Saat & 4 Saat & 1,67 Saat \\
\hline กั & & & & Haftada $1 \mathrm{Kez}$ & 16,66 & & & \\
\hline ○ீ & & & & Haftada $2 \mathrm{Kez}$ & 16,66 & & & \\
\hline & Tığ-dantel işleme & 4 & 20 & Her Gün & 25 & 1 Saat & 3 Saat & 1,75 Saat \\
\hline 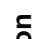 & & & & Haftada Bir Kez & 50 & & & \\
\hline$\overbrace{0}^{0}$ & & & & Haftada $2 \mathrm{Kez}$ & 25 & & & \\
\hline ఏ & Yemek yapma (pasta- & 4 & 20 & Haftada $1 \mathrm{Kez}$ & 75 & 1 Saat & 1 Saat & 1 Saat \\
\hline$\frac{\bar{v}}{0}$ & börek vb.) & & & Haftada $2 \mathrm{Kez}$ & 25 & & & \\
\hline$\vec{n}$ & Çiçek bakımı & 3 & 15 & Her Gün & 66,66 & 5 Dakika & 5 Dakika & 5 Dakika \\
\hline$\frac{N}{n}$ & & & & 2 Günde $1 \mathrm{Kez}$ & 33,33 & & & \\
\hline \& & Masa başı oyunlar & 2 & 10 & Haftada $1 \mathrm{Kez}$ & 50 & 1 Saat & 1 Saat & 1 Saat \\
\hline & (jenga,tabu, okey vb.) & & & Haftada $1 \mathrm{Kez}$ & 50 & & & \\
\hline & Dikiş dikme & 1 & 5 & Haftada 2 Kez & 100 & 1 Saat & 1 Saat & 1 Saat \\
\hline & Şenliğe katılma & 1 & 5 & Yılda $1 \mathrm{Kez}$ & 100 & 3 Saat & 3 Saat & 3 Saat \\
\hline & Misafirliğe gitme & 10 & 50 & Her Gün & 6,25 & 1 Saat & 8 Saat & 3,5 Saat \\
\hline & & & & 2 Günde $1 \mathrm{Kez}$ & 6,25 & & & \\
\hline & & & & Haftada $1 \mathrm{Kez}$ & 43,75 & & & \\
\hline & & & & Haftada $2 \mathrm{Kez}$ & 12,5 & & & \\
\hline & & & & 2 Haftada $1 \mathrm{Kez}$ & 6,25 & & & \\
\hline & & & & Ayda $1 \mathrm{Kez}$ & 25 & & & \\
\hline & Dış mekanda oturma & 7 & 35 & Her Gün & 25 & 1 Saat & 4 Saat & 2,87 Saat \\
\hline & (kafe, avm, bar vb.) & & & 2 Günde $1 \mathrm{Kez}$ & 12,5 & & & \\
\hline & & & & Haftada $1 \mathrm{Kez}$ & 50 & & & \\
\hline & & & & Ayda $1 \mathrm{Kez}$ & 12,5 & & & \\
\hline & Misafir kabul etme & 7 & 35 & Haftada $1 \mathrm{Kez}$ & 14,28 & 1 Saat & 5 Saat & 3,42 Saat \\
\hline & & & & Haftada $2 \mathrm{Kez}$ & 14,28 & & & \\
\hline & & & & Ayda $1 \mathrm{Kez}$ & 57,14 & & & \\
\hline & & & & 2 Ayda $1 \mathrm{Kez}$ & 14,28 & & & \\
\hline & Dolaşma (park vb.) & 5 & 25 & Her Gün & 40 & 1 Saat & 6 Saat & 3 Saat \\
\hline & & & & Haftada $1 \mathrm{Kez}$ & 40 & & & \\
\hline & & & & Haftada $2 \mathrm{Kez}$ & 20 & & & \\
\hline & Güne gitme & 3 & 15 & Haftada $1 \mathrm{Kez}$ & 33,33 & 3 Saat & 3 Saat & 3 Saat \\
\hline & & & & Ayda $1 \mathrm{Kez}$ & 66,66 & & & \\
\hline & Piknik yapma & 2 & 10 & Yılda $2 \mathrm{Kez}$ & 50 & 4 Saat & 12 Saat & 8 Saat \\
\hline & & & & Yılda $12 \mathrm{Kez}$ & 50 & & & \\
\hline & Sohbete gitme & 1 & 5 & Haftada $5 \mathrm{Kez}$ & 100 & 2 Saat & 2 Saat & 2 Saat \\
\hline
\end{tabular}


Tablo 7. MS öncesi aktif rekreasyon aktivitelerinin sıklıkları, süreleri ve yüzdeleri

\begin{tabular}{|c|c|c|c|c|c|c|c|}
\hline \multirow{3}{*}{ Aktivite } & \multirow{3}{*}{ Sayı } & \multirow{3}{*}{$\begin{array}{c}\text { Yüzde } \\
(\%)\end{array}$} & \multirow{2}{*}{\multicolumn{2}{|c|}{$\begin{array}{c}\text { Aktif Rekreasyon } \\
\text { Sıklık }\end{array}$}} & \multirow{2}{*}{\multicolumn{3}{|c|}{ Süre }} \\
\hline & & & & & & & \\
\hline & & & Sıklık & Yüzde (\%) & Min & Max & Ortalama \\
\hline \multirow{3}{*}{ Yürüyüş } & \multirow{3}{*}{11} & \multirow{3}{*}{55} & Her Gün & 81,81 & \multirow{3}{*}{0,5 Saat } & \multirow[t]{3}{*}{2 Saat } & \multirow{3}{*}{ 1,31 Saat } \\
\hline & & & 2 Günde $1 \mathrm{Kez}$ & 9,09 & & & \\
\hline & & & Ayda $1 \mathrm{Kez}$ & 9,09 & & & \\
\hline Tatile çıkma & 6 & 30 & Yılda $1 \mathrm{Kez}$ & 100 & 7 Gün & 30 Gün & 13 Gün \\
\hline \multirow[t]{5}{*}{ Sinemaya gitme } & \multirow[t]{5}{*}{5} & \multirow[t]{5}{*}{25} & 3 Haftada $1 \mathrm{Kez}$ & 20 & \multirow[t]{5}{*}{2 Saat } & \multirow[t]{5}{*}{2 Saat } & \multirow[t]{5}{*}{2 Saat } \\
\hline & & & Ayda $1 \mathrm{Kez}$ & 20 & & & \\
\hline & & & 2 Ayda $1 \mathrm{Kez}$ & 20 & & & \\
\hline & & & 3 Ayda $1 \mathrm{Kez}$ & 20 & & & \\
\hline & & & Yılda $5 \mathrm{Kez}$ & 20 & & & \\
\hline \multirow[t]{3}{*}{ Tiyatroya gitme } & \multirow[t]{3}{*}{4} & \multirow[t]{3}{*}{20} & 2 Ayda $1 \mathrm{Kez}$ & 25 & \multirow[t]{3}{*}{2 Saat } & \multirow[t]{3}{*}{2 Saat } & \multirow[t]{3}{*}{2 Saat } \\
\hline & & & Yılda $1 \mathrm{Kez}$ & 50 & & & \\
\hline & & & Yılda $5 \mathrm{Kez}$ & 25 & & & \\
\hline \multirow{3}{*}{$\begin{array}{l}\text { Meyve-sebze } \\
\text { toplama }\end{array}$} & \multirow[t]{3}{*}{3} & \multirow[t]{3}{*}{15} & Yılda $1 \mathrm{Kez}$ & 33,33 & \multirow[t]{3}{*}{1 Saat } & \multirow[t]{3}{*}{5 Saat } & 2,66 Saat \\
\hline & & & Yılda $5 \mathrm{Kez}$ & 33,33 & & & \\
\hline & & & Yılda $6 \mathrm{Kez}$ & 33,33 & & & \\
\hline Spor yapma & 3 & 15 & Haftada $2 \mathrm{Kez}$ & 100 & 0,5 Saat & 3 Saat & 1,5 Saat \\
\hline Yüzme & 3 & 15 & Yılda $7 \mathrm{Kez}$ & 33,33 & 2 Saat & 3 Saat & 2,33 Saat \\
\hline & & & Yılda $10 \mathrm{Kez}$ & 33,33 & & & \\
\hline & & & Yılda $15 \mathrm{Kez}$ & 33,33 & & & \\
\hline Futbol oynama & 2 & 10 & Haftada $1 \mathrm{Kez}$ & 33,33 & 1,5 Saat & 3 Saat & 2 Saat \\
\hline & & & Haftada $2 \mathrm{Kez}$ & 33,33 & & & \\
\hline & & & Haftada $3 \mathrm{Kez}$ & 33,33 & & & \\
\hline Voleybol & 2 & 10 & Haftada $1 \mathrm{Kez}$ & 50 & 1,5 Saat & 2 Saat & 1,75 Saat \\
\hline oynama & & & Yılda $30 \mathrm{Kez}$ & 50 & & & \\
\hline Dans etme & 1 & 5 & Yılda $3 \mathrm{Kez}$ & 100 & 30 Dakika & 30 Dakika & 30 Dakika \\
\hline Go-kart & 1 & 5 & Yıkda $3 \mathrm{Kez}$ & 100 & 15 Dakika & 15 Dakika & 15 Dakika \\
\hline Kamp yapma & 1 & 5 & Yılda $1 \mathrm{Kez}$ & 100 & 10 Gün & 10 Gün & 10 Gün \\
\hline Kartopu oynama & 1 & 5 & Yılda $5 \mathrm{Kez}$ & 100 & 1 Saat & 1 Saat & 1 Saat \\
\hline Kayak yapma & 1 & 5 & Yılda $1 \mathrm{Kez}$ & 100 & 3 Saat & 3 Saat & 3 Saat \\
\hline Kursa gitme & 1 & 5 & Haftada $1 \mathrm{Kez}$ & 100 & 2 Saat & 2 Saat & 2 Saat \\
\hline Tekvando & 1 & 5 & Haftada $1 \mathrm{Kez}$ & 100 & 2 Saat & 2 Saat & 2 Saat \\
\hline
\end{tabular}

Tablo 8. MS öncesi aktivitenin yapıldığı yerler ve aktivitelerin birlikte yapıldığı kişiler

\begin{tabular}{|c|c|c|c|c|}
\hline & & & & $\begin{array}{l}\text { Yüzde } \\
(\%)\end{array}$ \\
\hline \multirow{10}{*}{ 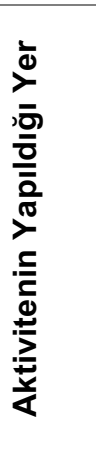 } & \multicolumn{3}{|l|}{ Yaşadığı ev } & 35,8 \\
\hline & \multicolumn{3}{|c|}{ Topluma açık yerler (dernek, kurs, sinema, tiyatro vb.) } & 19,3 \\
\hline & \multicolumn{3}{|l|}{ Başka birinin evi } & 14,2 \\
\hline & \multicolumn{3}{|l|}{ Açık hava (park, yol, vb.) } & 13,1 \\
\hline & \multirow{4}{*}{$\begin{array}{l}\text { Dış ortam (kafe-restoran, kahvehane, } \\
\text { binanın önündeki yer, avm) }\end{array}$} & Kafe-restoran & 58,6 & \multirow{4}{*}{10,9} \\
\hline & & Alış veriş merkezi & 31,0 & \\
\hline & & Kahvehane & 9,1 & \\
\hline & & Binanın önündeki yer-çardak & 6,9 & \\
\hline & Otel-yazlık & & & 3,6 \\
\hline & Yolda (toplu taşımada, arabada vb.) & & & 2,9 \\
\hline \multirow{10}{*}{ 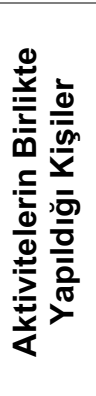 } & Yalnız & & & 31,8 \\
\hline & Arkadaşlar (MS hastası kişiler) & & & 13,1 \\
\hline & Anne, baba ya ve kardeş & & & 12,4 \\
\hline & Çocuklarıyla & & & 8,4 \\
\hline & Eş & & & 8,4 \\
\hline & Arkadaşlar & & & 8,0 \\
\hline & Akraba & & & 6,6 \\
\hline & Eşi ve çocuklarıyla & & & 5,5 \\
\hline & Toplum & & & 3,3 \\
\hline & Komşu & & & 2,6 \\
\hline
\end{tabular}


Hastalık sonrası kişiler aktif rekreasyon aktiviteleri yerine sosyalizasyon ve sessiz rekreasyon aktivitelerini tercih ettikleri bulundu (Grafik 1). Kişilerin MS öncesi ve sonrasındaki aktivite tercihleri Grafik 1'de karşılaştırmalı olarak gösterilmiştir. Kişilerin hastalık öncesi daha hareketli aktiviteleri tercih ederken hastalık sonrası hareketi az içeren aktivitelere yöneldikleri bulundu. Kişiler hastalık sonrası bazı sessiz rekreasyon aktivitelerinin sürelerinde azalma bulundu. Kitap okuma, tığ-dantel işleme ve yemek yapma aktivitelerinin sürelerinde azalma görülürken örgü örme ve çiçek bakımı aktivitelerinin sürelerinde artış bulundu (Grafik 2).

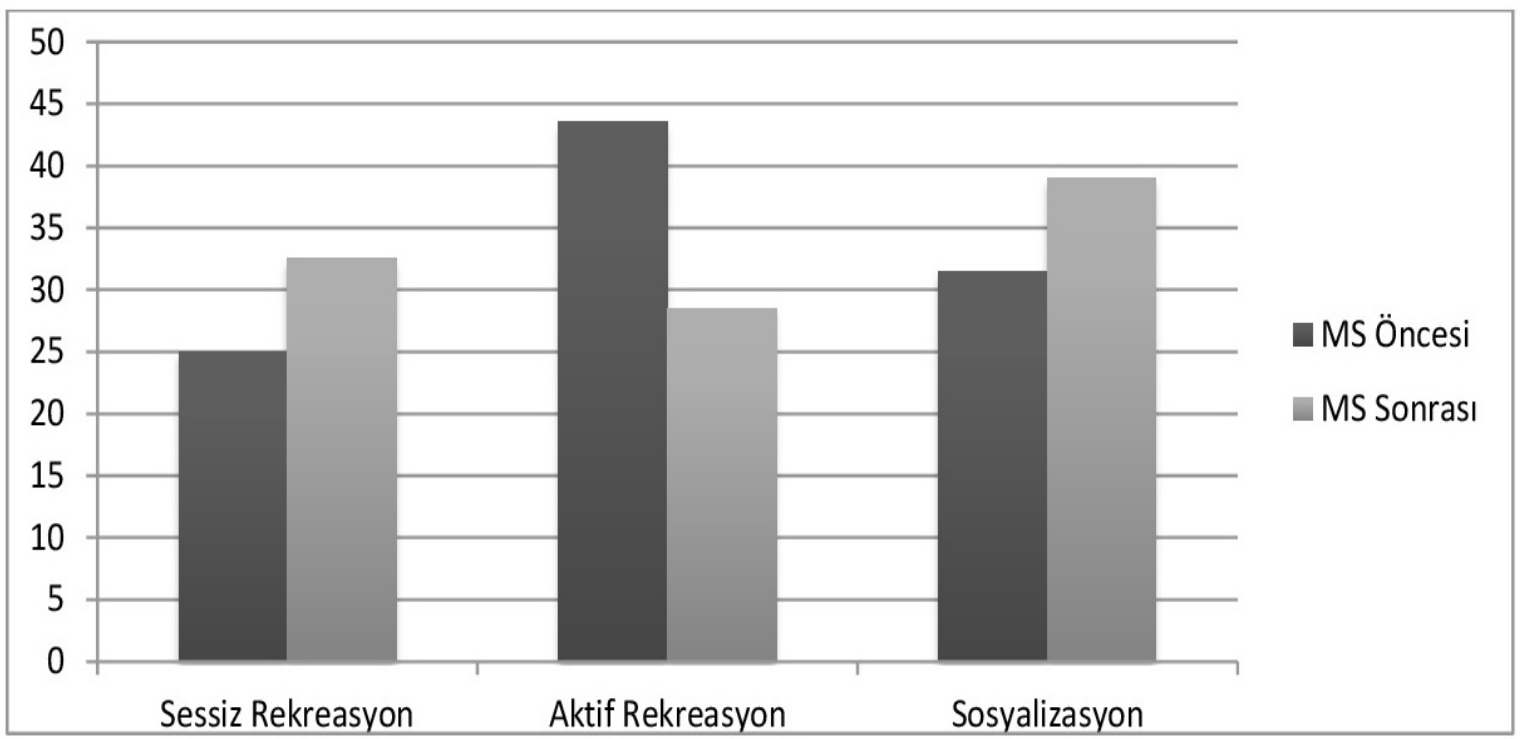

Grafik 1. MS öncesi ve sonrası sessiz rekreasyon, aktif rekreasyon ve sosyalizasyon aktivitelerinin karşılaştırmalı olarak sütun grafiğinde gösterimi (\%)

Kişiler hastalık sonrası bazı aktif rekreasyon aktivitelerinin sürelerinde azalma görülmüştür. Yürüyüş, yüzme, spor yapma, meyve ve sebze toplama aktivitelerinin sürelerinde azalma görülürken kursa katılım süreleri artmıştır (Grafik 2). Kişiler hastalık sonrası kursa gitme yüzdelerinin arttığı saptandı (Grafik 2). Tatile çıkma süresi hastalıktan sonra artmıştır. Hastalıktan önce 13 günken hastalıktan sonra 20,22 gün olmuştur ve katılımcıların tatile gitme yüzdesi hastalıktan önce \%30'ken hastalıktan sonra \%45 olduğu saptandı. Hastalıktan sonra sinemaya gitme sıklığının arttığı bulunurken tiyatroya gitme yüzdesinin azaldığı bulundu (Tablo 4 ve Tablo 8). Kişilerin bazı sosyalizasyon aktivitelerinde; misafirliğe gitme, dış mekanda oturma, misafir kabul etme, piknik ve güne gitme aktivitelerinin sürelerinin hastalık sonrasında azaldığı bulundu (Grafik 2). (Grafik 2 burada yer alacaktır.) 


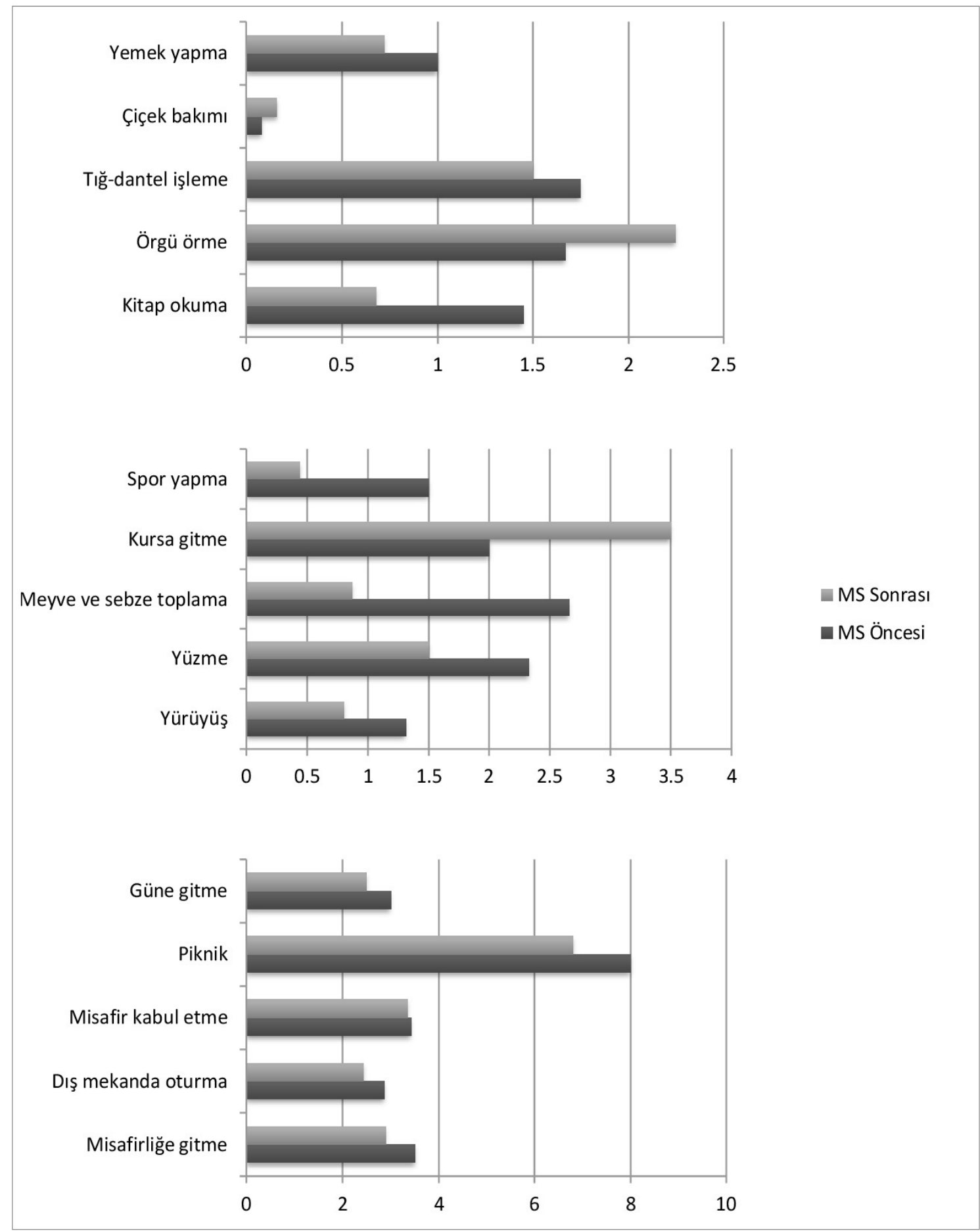

Grafik 2. MS öncesi ve sonrasında yapılan bazı sessiz rekreasyon, aktif rekreasyon ve sosyalizasyon aktivitelerinin sürelerinin karşılaştırmalı olarak sütun grafiğinde gösterimi (\%)

Hastalıktan önce kişilerin \%28,8'i arkadaşlarıyla vakit geçirirken hastalıktan sonra \%8'i arkadaşlarıyla vakit geçirdikleri bulundu. Ayrıca hastalıktan sonra kişilerin \%13,1'i MS'li kişilerle vakit geçirdiği saptandı (Grafik 3). Hastalık öncesi \%22,0 açık havada ve \%18,6 topluma açık yerlerde (spor salonu, kurs, sinema vb.) yerleri tercih ederken hastalık sonrası \%13,1 açık havada ve \%19,3 dernek, kurs gibi yerleri tercih ettikleri bulundu (Grafik 3). Ayrıca kişiler dış ortamda kafe, restoran hastalık öncesinde \%63,6 iken hastalık sonrası $\% 58,6$ 'dır. Alışveriş merkezine gitme hastalık sonrası artmıştır. Hastalıktan önce alışveriş merkezlerine gitme $\% 9,1$ 'ken hastalıktan sonra $\% 31$ olmuştur (Grafik 4). Hastalıktan sonra kişiler MS derneğinde vakit geçirmeye başlamışlardır. 


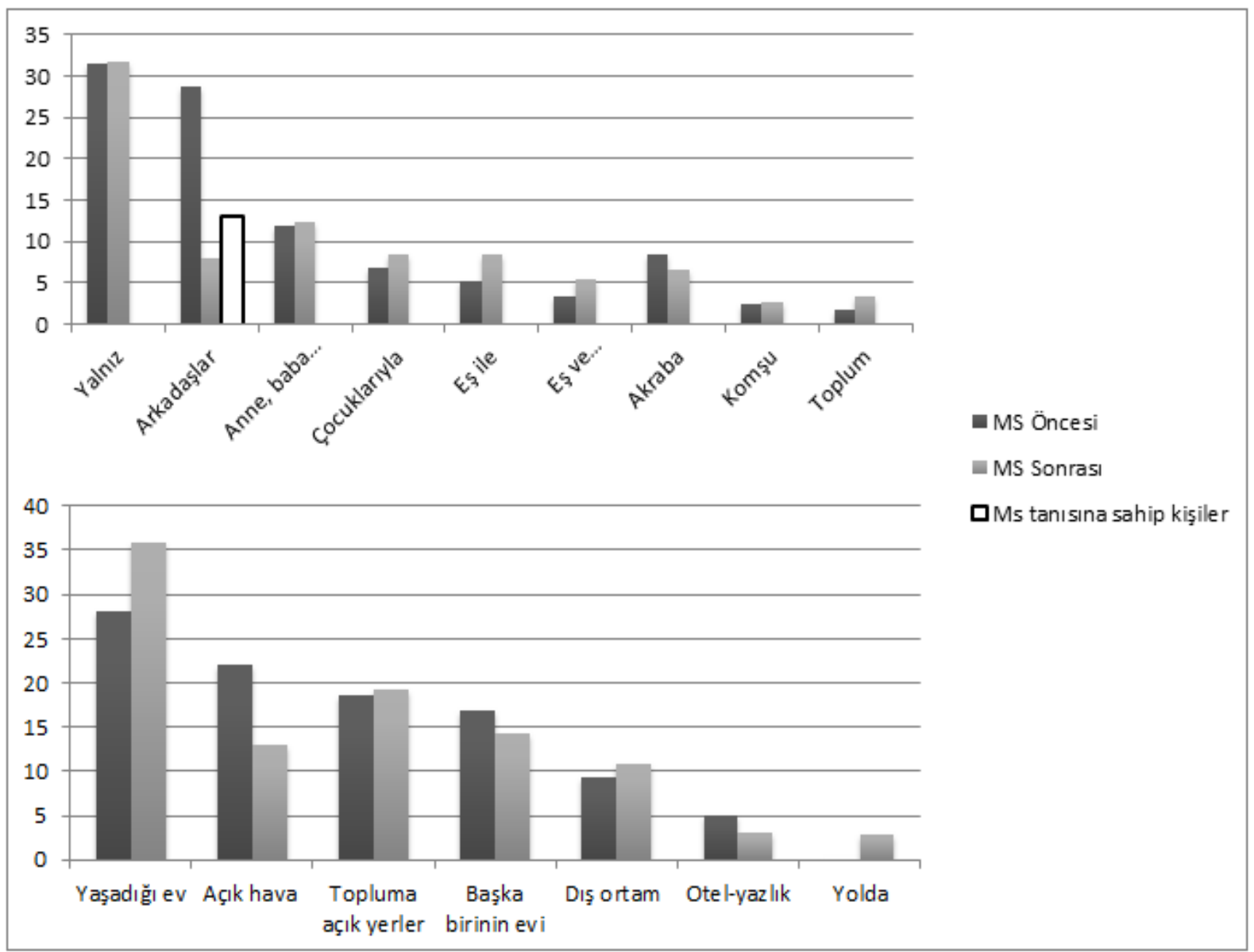

Grafik 3. MS öncesi ve sonrasında serbest zaman aktivitelerinin birlikte yapıldığı kişilerin ve yapıldığı yerlerin karşılaştırmalı olarak sütun grafiğinde gösterimi (\%)

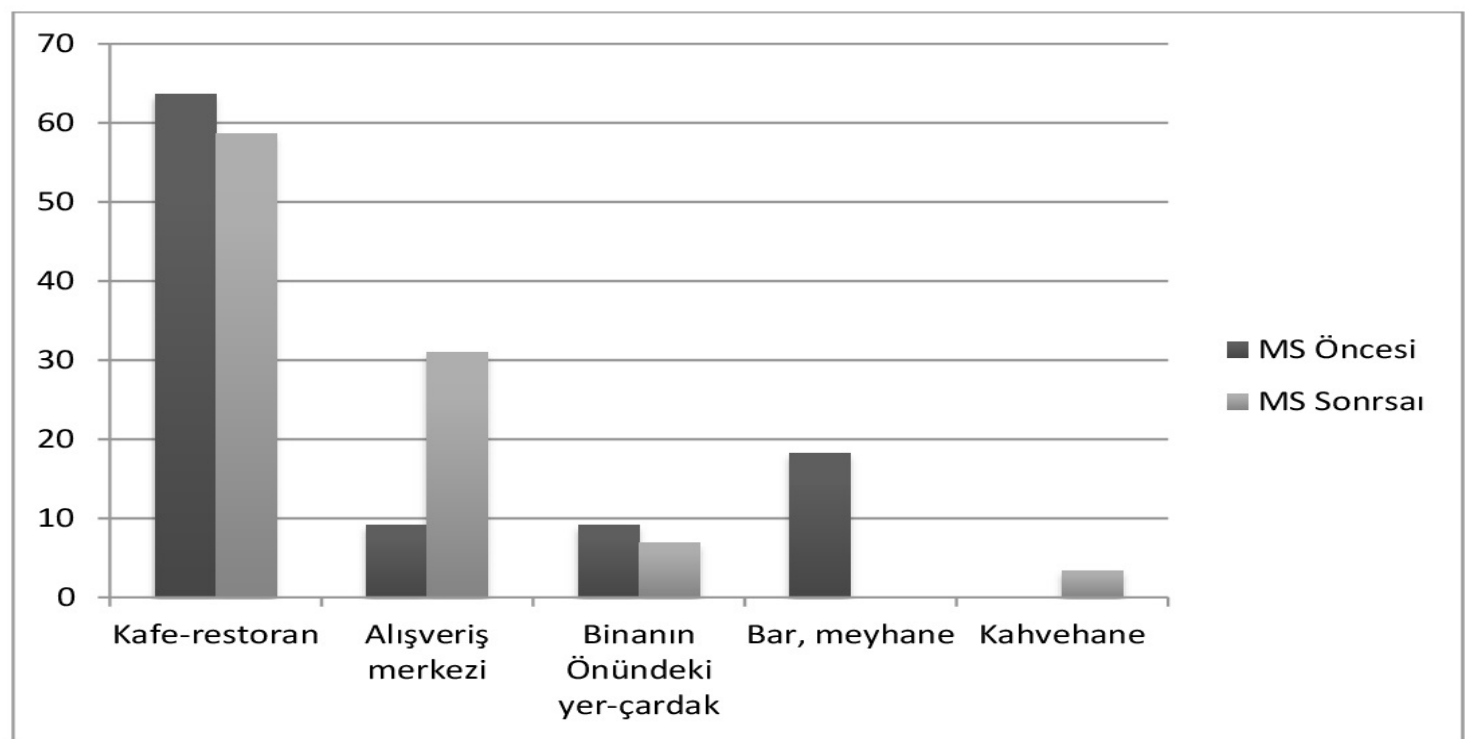

Grafik 4. MS öncesi ve sonrasında dış ortamda yapılan serbest zaman aktivitelerin yerlerinin karşılaştırmalı olarak sütun grafiğinde gösterimi (\%) 
Katılımcılardan 14'ü hastalığının serbest toplumsal cinsiyet rolleri, cinsiyete dayalı önyargı zaman aktivitelerini etkilediğini, 1'i kısmen ve ataerkil toplumsal yapı olarak sayılabilir etkilediğini ve 5'i etkilemediğini düşünüyor. 14 (Henderson, 1990). Bu doğrultuda çalışmamızdaki katılımcı hastalıktan sonra serbest zaman katılımcıların çoğu kadındır ve aktivitelere katılım aktivitelerinde değişim olduğunu, 1 kişi kısmen oranı kadınlarda erkeklere göre daha fazla olduğu değişim olduğunu ve 5 kişi değişim olmadığını belirtti.

\section{MS Ille Değişen Aktivite Bulguları}

Görüşmeden elde edilen nitel sonuca göre üç temel başlık elde edilmiştir; aktivitenin süresini azaltma (kitap okuma aktivitesinde 5 dakika okuduktan sonra ara verme gibi), aktiviteyi farklı şekilde yapma (ağaçtan meyve toplarken sadece elinin uzandığı yerlerden toplama gibi) ve aktiviteyi yapmayı bırakma (tığ işlerken yapılan yuvarlak şekillerin birbirine benzememesi ve şeklin giderek kayması sonucu aktiviteyi tekrar yapmama gibi). Genel olarak kişiler aktiviteleri yaparken dikkat ettiklerini ve kendilerini yormayacak şekilde aktiviteleri gerçekleştirdiklerini belirttiler.

Kişilerin çoğunda hafta içi ve hafta sonu aktivite tercihlerinde değişim olmadığı gözlendi ancak çalışan bazı kişiler hafta sonu serbest zaman aktivitelerine zaman ayırdıkları saptandı. Hafta sonları genelde katılımcılar alışveriş merkezi ve MS derneğine katıldıkları bulundu. Mevsime göre aktivite tercihlerinde bahar ve yazın dönemlerinde değişen aktiviteler olduğu saptandı. Kişiler bu mevsimlerde yürüyüş, tatile çıkma, memlekete gitme, yüzme, meyve-sebze toplama ve toprak işleriyle uğraşma aktivitelerini yapmaktadırlar.

\section{TARTIŞMA}

MS'li kişilerin yaptığı serbest zaman aktivite tercihlerini belirlemek ve MS tanısı ile değişen serbest zaman aktivitelerini saptamak amacıyla yapılan çalışmada MS'li kişilerin hastalık sonrası sessiz rekreasyon ve sosyalizasyon aktivitelerini tercih ettikleri saptanmıştır. Kişiler hastalık sonrası serbest zaman aktivitelerini evde ve yalnız yapmayı tercih etmektedirler. Kişiler hastalıktan önce aktif rekreasyon aktivitelerini tercih etmekteydiler ve aktiviteleri arkadaşlarıyla, evde ve açık havada yapmayı tercih ediyorlardı.

Kara, Gürbüz ve Öncü'nün çalışmasına göre serbest zaman sıkıntı algısı cinsiyet açısından anlamlı fark bulunmamıştır ama erkeklerin kadınlara göre memnuniyet puanları daha yüksektir (Kara, Gürbüz ve Öncü, 2014). Bu sonuçta, çeşitli faktörler cinsiyetler arasındaki motivasyonel farklılıklara neden olabilir. Bunlar; her şeyi çocuklarına göre ayarladıklarını belirtti. Bir katılımcıda aktiviteyi seçerken çocuğunun sevdiği aktiviteleri tercih ettiğini belirtti. Bu sonuçlar doğrultusunda aktivite memnuniyeti ve çocuk varlığının aktivite tercihlerine etkisi açısından daha detaylı bir inceleme yapılabilir.

Büküşoğlu ve Bayturan'ın çalışmasına göre serbest zaman etkinliklerinin gençlerde olumlu kişilik özelliklerinin gelişmesinde ve ruh sağlıklarını korumada yardımcı olduğu bulunmuştur (Büküşoğlu ve Bayturan, 2005). Bunun doğrultusunda MS'li kişilerde serbest zaman aktivitelerinin, kişilerin motivasyonun arttırılmasında ve ruh halinin korunmasında etkili olabileceği düşünülmektedir.

Akgül, Ayyıldız ve Karaman'ın çalışmasına göre serbest zaman tatmin düzeyi gelir durumuna göre değişmektedir (Akgül, Ayyıldız ve Karaman, 2014). Geliri yüksek olanların orta ve düşük olanlara göre daha yüksek olduğu saptanmıştır. Buna göre çalışmamızdaki kişilerin gelir düzeyleri farklılık göstermektedir. Kişilerdeki farklılık serbest zaman aktivite tercihini ve aktiviteyi yapma sıklığını etkilediği düşünülmektedir. Görüşmeler esnasında bir katılımcı aktiviteleri maddi durumunu göz önünde bulundurarak yaptığını belirtmişti.

Kara ve Gücal'ın çalışmasına göre akademisyenlerin serbest zaman aktivitelerini bulamadıkları ya da aktivitelerinden haz almadıkları için iş ve üretici aktivitelerine daha fazla zaman ayırdıkları bulunmuştur (Kara ve Gücal, 2016). Bu çalışmada kişilerin iş ve üretici aktivitelere daha fazla zaman ayırmaları nedeniyle aktivite dengesi bozulmaktadır. $\mathrm{Bu}$ nedenle çalışmamızla benzerlik göstermektedir. Çalışmamızdaki kişilerde hastalık sonucu oluşan semptomlar nedeniyle serbest zaman aktivitelerine daha az zaman ayırmaktadırlar. Bir katılımcı kendine bakım aktivitelerini yaparken fazla zaman harcadığı için serbest zaman aktivitesi yapmaya vakti kalmadığını belirtmişti.

Sadegh Hosseini ve arkadaşlarının çalışmasında serbest zaman aktivitelerini altı sınıfa ayırmışlardır (fiziksel, sosyal, bireysel, manevi/dini, kültürel ve eğitici) ve bu sınıfların önemini vurgulamışlardır (Hosseini ve ark, 2016). Çalışmada fiziksel ve eğitici sınıflardaki aktivite 
çeşitliliği diğer sınıflardaki aktivite çeşitliliğine göre daha azdır ve çalışmamızdaki katılımcıların hastalık sonrasında aktif rekreasyon aktivitelerini daha az tercih ettikleri saptanmıştır. Bu doğrultuda tedavide serbest zaman aktivitelerinde aktif rekreasyon aktivitelerine katılımı geliştirmemize yönelik bir sonuç vermiştir.

Çalışmamızdaki katılımcılar Sadegh
Hosseini'nin ayırdığı sınıflara göre televizyon izleme, misafirliğe gitme, telefonla konuşma ve müzik dinleme aktivitelerini tercih etmeleri benzerlik gösterse de fiziksel sınıfta bisiklete binme ve koşu bandı kullanma, bireysel sınıfta telefonda oyun oynama ve ev eşyalarını onarma, dini sınıfta dini hikayeler okuma, ilahi dinleme ve dini törene katılma, kültürel sınıfta çömlek üzerine boyama yapma ve enstrüman çalma, eğitici sınıfta birine İngilizce öğretme, camsı emaye yapmayı öğrenme ve hattatlık aktivitelerini tercih etmemeleri açısından farklılık göstermektedir. Bu aktiviteleri tercih etmemelerinde kültürün etkisi olabilir.

Fitts ve Howe'un çalışmasında kardiyak hastası kişiler en çok televizyon izleme, kitap okuma, dışarı çıkma, müzik dinleme ve telefonla konuşma aktivitelerini tercih etmektedirler (Fitts ve Howe, 1987). MS'li ve kardiyak hastası kişiler televizyon izleme, kitap okuma ve telefonla konuşma aktiviteleri tercihleri açısından benzerlik göstermektedir. Ancak kardiyak hastası kişiler MS'li kişilere göre daha fazla fiziksel aktivite içeren aktiviteler tercih ettikleri görülmüştür. Bunun nedeni MS hastalığında kişide oluşan fiziksel bozukluklardan kaynaklı olduğu düşünülmektedir.

Mansuroğlu'nun çalışmasına göre eğitim gören sağlıklı olan kişilerin serbest zaman kavramını bilmediği saptanmıştır (Mansuroğlu, 2002). Çalışmamız da katılımcıların çalışan yüzdesinin (\%25) az olması açısından benzerlik göstermektedir. Çalışmamızda katılımcıların serbest zaman kavramını yeterli bilmedikleri nedeniyle görüşmelerin başında kişilere serbest zaman aktiviteleri anlatılmıştır. Görüşmelerde kişiler alışveriş merkezine gitmeyi serbest zaman aktivitesi olarak belirtmişlerdir. Aslında bu aktivite yardımcı günlük yaşam aktivitesidir ve bu nedenle bir rol karmaşası vardır.

Kişiler her hafta cumartesi günü MS derneğinde verilen yoga derslerine katılmaktadır. Kişiler yoganın kendilerini rahatlattığını ve motive ettiğini söylemektedirler. Literatürde yoganın MS'li hastalar için yararlı olduğu gösterilmiştir (Ahmadi,
Nikbakh, Arastoo ve ark, 2010). Yapılan uygulamalar kişilerin motivasyonunu ve sosyal katıımını arttırmaktadır. Dernekler ve kuruluşlar desteklenerek bu tarz uygulamalar arttırılabilir ve böylelikle kişilerin yaşam kaliteleri ve katılımları desteklenebilir.

Görüşmeler esnasında katılımcılar ile MS öncesinde yaptıkları aktiviteler hakkında konuşurken duygusallaştılar ve bu konuda pek konuşmak istemediler. Bir katılımcı eski kendisini gömdüğünü ve artık o kişiyi unuttuğunu belirtti. Aktiviteleri detaylı vermekten kaçındılar ve daha çok şimdi yapamadıkları aktiviteleri ilk olarak söylediler. Bu nedenle MS'li kişilerle eski durumları hakkında konuşurken anlayışlı ve motive edici yönde konuşulmalıdır.

Kişilerde hastalık sonucu oluşan limitasyonlar ve komplikasyonlarda serbest zaman aktivitelerini etkilemektedir. Aktivite tercihleri incelenirken demografik farklılıklar ve bozukluklara göre incelenebilir.

MS'li kişilerin hastalık sonucu oluşan limitasyonlar ve komplikasyonlar nedeni ile yapmayı bıraktıkları serbest zaman aktiviteleri analiz edilerek problemli alanlar kompansatuar teknikler ve yardımcı teknoloji ile desteklenebilir.

\section{Kaynaklar}

Ahmadi, A., Nikbakh, M., Arastoo, A. A., \& Habibi, A. H. (2010). The effects of a yoga intervention on balance, speed and endurance of walking, fatigue and quality of life in people with multiple sclerosis. J Hum Kinet, 23(2), 71-78.

Akgül, B. M., Ayyıldız, T., \& Karaman, M. (2014). Spor merkezlerinde rekreatif faaliyetlere katılan bireylerin serbest zaman tatmin düzeylerinin farklı değişkenlere göre incelenmesi. Beden Egitimi ve Spor Bilimleri Dergisi, 8(3), 278-287.

American Journal of Occupational Therapy (2014). Occupational therapy practice framework: domain and process (3rd ed). Am J Occup Ther, 68(Supplement 1), S1-S48.

Büküşoğlu, N., \& Bayturan, A. F. (2005). Serbest zaman etkinliklerinin gençlerin psiko-sosyal durumlarına ilişkin algısı üzerindeki rolü. Ege Tıp Dergisi, 44(3), 173-177.

Chang, S. C., Fang, C. L., Ling, Y. C., \& Tsai, B. K. (2011). Effects of socioeconomic status on leisure volunteering constraints: A structural equation model. Soc Behav Personal, 39(4), 477-490.

Edgelow, M., \& Krupa, T. (2011). Randomized controlled pilot study of an occupational time-use intervention for people with serious mental illness. Am J Occup Ther, 65(3), 267-276.

Etemadifar, M., Izadi, S., Nikseresht, A., Sharifian, M., 
Sahraian, M. A., \& Nasr, Z. (2014). Estimated prevalence and incidence of multiple sclerosis in Iran. Eur Neurol, 72(5-6), 370-374.

Fitts, H. A., \& Howe, M. C. (1987). Use of leisure time by cardiac patients. Am J Occup Ther, 41(9), 583-589.

Henderson, K. A. (1990). The meaning of leisure for women: An integrative review of the research. J Leisure Res, 22(3), 228-243.

Hersch, G. I., Lamport, N. K., \& Coffey, M. S. (2005). Activity analysis: application to occupation (5th ed). New Jersey:SLACK Incorporated.

Hosseini, S. M., Asgari, A., Rassafiani, M., Yazdani, F., \& Mazdeh, M. (2016). Leisure time activities of Iranian patients with multiple sclerosis: a qualitative study. Health Promot Perspect, 6(1), 47-53.

Kara, F. M., \& Gücal, A. Ç. (2016). Akademisyenlerde işkolikliğin belirlenmesinde serbest zamanda sıkılma algısının rolü. Başkent Üniversitesi Sağlık Bilimleri Fakültesi Dergisi, 1(1), 47-62.

Kara, F. M., Gürbüz, B., \& Öncü, E. (2014). Leisure boredom scale: the factor structure and the demographic differences. Turkish Journal of Sport and Exercise, 16(2), 28-35.

Mansuroğlu, S. (2002). Akdeniz Üniversitesi öğrencilerinin serbest zaman özellikleri ve dış mekan rekreasyon eğilimlerinin belirlenmesi. Mediterranean Agricultural Sciences, 15(2), 53-62.

Marrie, R. A., Horwitz, R., Cutter, G., \& Tyry T. (2012). Cumulative impact of comorbidity on quality of life in MS. ActaNeurol Scand, 125(3), 180-186.

McHugh Pendleton, H., \& Schultz-Krohn, W. (2013). Pedretti's Occupational Therapy: Practice Skills for Physical Dysfunction (7th ed). Missouri: Elsevier Health Sciences.

Murray, T. J. (2005). Multiple Sclerosis:The History of A Disease. Demos: New York Press.

Radomski, M. V., \& Latham, C. A. (2008). Occupational Therapy for Physical Dysfunction (6th ed). Philadelphia: Lippincott Williams \& Wilkins.

Shevil, E. B., Johansson, S., Ytterberg, C., Bergström, J., \& Koch, L. V. (2014). How are cognitive impairment, fatigue and signs of depression related to participation in daily life among persons with multiple sclerosis? Disabil Rehabil, 36(23), 2012-2018.

Ünal, A., Mavioğlu, H., \& Emre, U. (2013). Multipl Sklerozda Tanı ve Tedavi Klavuzu. İstanbul: Publishing House.

Vanner, E. A., Block, P., Christodoulou, C. C., Horowitz, B. P., \& Krupp, L. B. (2008). Pilot study exploring quality of life and barriers to leisure-time physical activity in persons with moderate to severe multiple sclerosis. Disabil Health J, 1(1), 58-65.

Yıldırım, A., \& Şimşek, H. (2016). Sosyal Bilimlerde Nitel Araştırma Yöntemleri (10. bs.). Ankara: Seçkin Yayıncilık. 